\title{
PERFORMANCE DETERIORATION OF THERMOSIPHON SOLAR FLAT PLATE WATER HEATER DUE TO SCALING
}

\author{
Arunchala U.C. \\ Department of Mechanical and Manufacturing Engineering, \\ Manipal Institute of Technology, Udupi - 576104, Karnataka, India \\ arunchandavar@yahoo.co.in
}

\begin{abstract}
The performance of Flat plate Solar Water Heater deteriorates within five to twelve years of their installation due to factors related to manufacturing, operating conditions, lack of maintenance etc. Especially, problem due to scaling is significant as it is based on quality of water used. The remaining factors are system dependent and could be overcome by quality production. Software is developed by incorporating Hottel Whillier Bliss (H-W-B) equation to ascertain the effect of scaling on system efficiency in case of thermosiphon system. In case of clean thermosiphon system, the instantaneous efficiency calculated at $1000 \mathrm{~W} / \mathrm{m}^{2}$ radiation is $72 \%$ and it drops to $46 \%$ for $3.7 \mathrm{~mm}$ scale thickness. The mass flow rate is reduced by $90 \%$ for $3.7 \mathrm{~mm}$ scale thickness. Whereas, the average temperature drop of water in the tank is not critical due to considerable heat content in water under severe scaled condition. But practically in case of major scale growth, some of the risers are likely to get blocked completely which leads to negligible temperature rise in the tank.
\end{abstract}

\begin{abstract}
ABSTRAK: Prestasi plat rata pemanas air suria merosot selepas lima hingga dua belas tahun pemasangannya disebabkan faktor-faktor yang berkaitan dengan pembuatannya, cara kendaliannya, kurangnya penyelenggaraan dan sebagainya. Terutama sekali, masalah disebabkan scaling (tembunan endapan mineral) perlu diambil berat kerana ianya bergantung kepada kualiti air yang digunakan. Faktor-faktor selebihya bersandarkan sistem dan ia boleh diatasi dengan mempertingkatkan kualiti pembuatannya. Perisian komputer dihasilkan dengan menggunakan persamaan Hottel Whillier Bliss $(H-W-B)$ untuk menentukan kesan scaling terhadap kecekapan sistem dalam termosifon. Dalam sistem termosifon bersih, kecekapan seketika dikira pada $1000 \mathrm{~W} / \mathrm{m}^{2}$, pada kadar radiasi $72 \%$ dan ianya jatuh kepada $46 \%$ untuk ketebalan skala $3.7 \mathrm{~mm}$. Kadar aliran jisim berkurangan sebanyak $90 \%$ untuk ketebalan skala $3.7 \mathrm{~mm}$. Manakala, penurunan suhu purata air di dalam tangki tidaklah kritikal, disebabkan oleh kandungan haba yang tinggi di dalam air di bawah keadaan kerak yang teruk. Tetapi dalam kes tumbesaran kerak yang genting, sesetengah penaik akan tersumbat sepenuhnya, mengakibatkan peningkatan suhu di dalam tangki boleh diabaikan.
\end{abstract}

KEYWORDS: thermosiphon system; scaling; instantaneous efficiency; $H$-W-B equation

\section{INTRODUCTION}

The statistics reflect the reserves of fossil fuels that currently power society and their harmful side effects such as pollution that threatens human health and greenhouse gases 
associated with climate change. Hence finding sufficient supplies of clean energy for the future is one of society's most daunting challenge.

Renewable sources are being thought of as additional resources rather than as substitutes or alternatives because of their inherent nature. The use of non-hydro modern renewable energy technologies (including wind, solar, geothermal, tide and wave energy, and bioenergy) sees the fastest rate of increase in the present energy scenario. Now a days both solar electricity and thermal systems are popular. In thermal route particularly low and medium thermal systems have wide publicity due to simple design and low operating and maintenance cost. These are meant for water heating, steam generation, refrigeration etc. Solar thermal heating provides an elegant direct route of energy conversion without going through the route of coal thermal plant - electrical energy - transmission - distribution - resistance heating. Use of sun's energy to heat water is not a new idea. More than one hundred years ago, black painted water tanks were used as simple Solar Water Heaters (SWH) in a number of countries.

The Flat plate Solar Water Heaters (FSWH) is widely used today for the collection of low temperature solar thermal energy. Numerous studies have been performed particularly on thermosiphon SWH systems since they have the advantage of avoiding a water pump for circulating water in the collector.

The thermosiphon FSWH had been designed, tested and experimentally validated under no draw off condition by Close [1]. Here the insolation curve for a clear day is predicted from empirical data, which shows good agreement with experimental result. Similar study is carried out by Gupta and Garg [2] using FORTRAN II. A test procedure to estimate the daily mean values of the $\mathrm{H}-\mathrm{W}-\mathrm{B}$ constants from the measured variation of the storage tank temperature is investigated by Wijeysundera et al. [3]. Two flat-plate collectors were tested over a period of 11 days each to study the feasibility of the test procedure. The tests were conducted under variable weather conditions and inlet water temperatures. The standard deviations for the daily mean values of $\mathrm{H}-\mathrm{W}-\mathrm{B}$ constants were about 2.8 percent and 4 percent, respectively. The differences between the daily mean values obtained by the proposed method and the steady-state test values for a 0 are about 4 percent to 7 percent, while for a1 the differences are 9 percent to 13 percent. The collector efficiency is dependent on the temperature of the plate which in turn is dependent on the nature of flow of fluid inside the tube, solar insolation, ambient temperature, top loss coefficient, the emissivity of the plate and glass cover, slope, etc. Theoretical and experimental analysis performed on a FPC by Raja Sekhar et al. [4] concluded that the emissivity of the absorber plate has a significant impact on the top loss coefficient and consequently on the efficiency of the FPC. Based on the literature review on FSWH, it is concluded that design method, fabrication procedure and performance tests are well established.

In SWH i.e. absorber tubes and heat exchanger, scaling can reduce heat transfer due to the additional conductive resistance across the scaled layer, and increase the fluid pressure drop due to narrowing of the flow passage.

Scaling tendency in case of cross-linked polyethylene (PEX), polypropylene random copolymer (PP-r) and copper tubes are studied by Sanft et al. [5]. The water with total calcium and carbonate concentration of $3 \times 10^{-3} \mathrm{M}$ and a $\mathrm{pH}$ of approximately 9.1, yielding a supersaturation of 7.8, was pumped through the tubes at a velocity of $0.07 \mathrm{~m} / \mathrm{s}$ for $2.5,5$, and $7.5 \mathrm{~h}$. The flow was laminar with Reynolds numbers of $>1000$. The result shows scaling rates 
respectively $5.1 \times 10^{-4}, 8.3 \times 10^{-4}$ and $3.0 \times 10^{-4} \mathrm{~g} / \mathrm{m}^{2} \mathrm{~s}\left(\mathrm{CaCO}_{3}\right)$ when the specimens were exposed to $7.5 \mathrm{~h}$. Wu et al.[6] presented an experimental study of scaling of polypropylene and copper tubes exposed to flowing tap water over an eight week period. The chemistry of the tap water is controlled to provide mildly supersaturated conditions at $\mathrm{pH}$ equal to 8 and $40^{\circ} \mathrm{C}$. The scaling rates for polypropylene and copper tubes are $0.8 \times 10^{-10}$ and $1.7 \times 10^{-10}$ $(\mathrm{mol} \mathrm{Ca}) /\left(\mathrm{m}^{2} \mathrm{~s}\right)$, respectively. Study by Baker and Vliet [7], compared different indirect SWH designs in regard to their susceptibility to problematic scaling using software TRNSYS. The results predicted the wrap-around design's performance to be less affected by scale than the external heat exchanger design.

Literature to date has focused on scaling effect in heat exchangers, flow systems and heat exchanger type SWH. However, information related to quantifying the effect of scaling on the performance of direct SWH systems is inadequate.

\section{SOLAR WATER HEATERS}

Broadly speaking, the SWH are of three categories viz. Heat exchanger type, Evacuated tube and Flat plate type. They receive both beam and diffuse solar radiation and do not require tracking of the sun. Mostly, both Heat exchanger and Evacuated tube types are installed in places where water hardness is considerable. The removal of scale deposited over the heat transfer surface is quite easy in both the systems. But, these systems are not as simple as FSWH. Hence FSWH is very popular due their work simplicity, robust design and low maintenance cost. Either thermosyphon or forced circulation mode is adopted in this case. In case of thermosiphon system as shown in Fig.1, the water passing through the riser gets heated up and is delivered to the storage tank due thermosiphon effect. The re-circulation of the same water through absorber panel in the collector raises the temperature to around $80^{\circ} \mathrm{C}$ on a good sunny day. The bottom of storage tank is atleast a feet higher than the top of the collector to avoid reverse flow during the night. Thermosiphon systems still remain as one of the most interesting technologies for exploitation of solar energy. Their remarkable efficiencies, combined with simplicity of construction, autonomy in operation, absence of moving parts and thus the minimization of necessary maintenance, make them an interesting alternative to forced circulation systems.

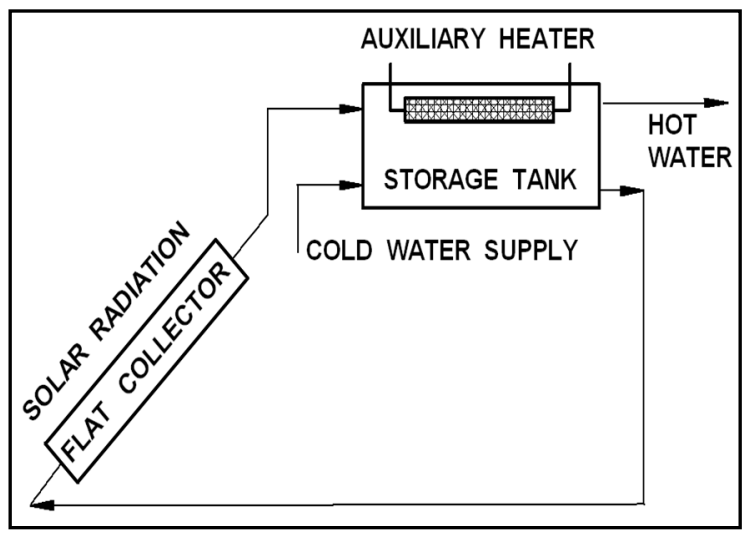

Fig. 1: Thermosiphon system. 


\section{PERFORMANCE DETERIORATION ANALYSIS OF FSWH}

Impurities present in water used for heating purpose in Flat Plate Collector (FPC), forms deposits in the flow passage. This process of deposition of chemicals on surface is called scaling. It affects both heat transfer and fluid flow. Scaling can only occur from water which is supersaturated with respect to a scaling salt, and such kind of water is often described as being hard. Calcium carbonate is the most common type of scale produced from domestic water. Software called FLATSCALE is developed by incorporating Hottel Whillier Bliss (HW-B) equation to ascertain the effect of scaling on energy efficiency indices like instantaneous efficiency, mass flow rate, overall heat loss coefficient etc. in case of thermosiphon system.

The various parameters which deteriorate the performance of thermosiphon FSWH due to scaling are discussed here.

The instantaneous efficiency is given by

$$
\eta_{i}=\frac{Q_{u}}{I A_{c}}
$$

The useful heat gain from the system is

$$
Q_{u}=A_{p} S-U_{l} A_{p}\left(T_{p}-T_{a}\right)
$$

The heat loss and gain can thus be calculated, if the average plate temperature is known. However, this temperature is generally not known. It will, therefore, be necessary to consider the flow of heat in the absorber plate and across the fluid tubes to the fluid so that the values of $T_{p}$ can be related to the value of the inlet fluid temperature, which is a known quantity. Hence Equation (1) is further modified as

$$
\eta_{i}=F_{R} \frac{A_{p}}{A_{c}}\left[\tau \alpha-U_{l} \frac{\left(T_{1}-T_{a}\right)}{I}\right]
$$

Collector heat removal factor $\left(F_{R}\right)$ is the ratio of the actual useful heat gain to the gain which would occurs if the collector absorber plate was at the temperature of water inlet.

$$
F_{R}=\frac{\dot{M} C_{p}}{U_{l} A_{p}}\left\{1-\exp \left[-\frac{F^{\prime} U_{l} A_{p}}{\dot{M} C_{p}}\right]\right\}
$$

In terms of heat transfer resistances along the heat flow path from the absorber plate to water, Collector efficiency factor $\left(F^{\prime}\right)$ can be written for scaled FPC as [8],

$$
F^{\prime}=\frac{1}{W U_{l}\left[\frac{1}{U_{l}\left[\left(W-d_{o}\right) \phi+d_{o}\right]}+\frac{1}{\pi d_{S} h}+\frac{1}{\frac{2 \pi k_{r}}{\ln \left(d_{o^{\prime}} d_{i}\right)}}+\frac{1}{\frac{2 \pi k_{S}}{\ln \left(d_{i^{\prime}} d_{S}\right)}}\right]}
$$

In Eq. (5), the last term in the denominator accounts for the thermal resistance of the scale. Figure 2 illustrates various dimensions of a riser with scaling. 
Since the value of $F_{R}, \tau \alpha$ and $U_{l}$ are essentially constant, for the given FPC design and its working condition, it is seen from Eq. (3) that if $\eta_{i}$ is plotted against $\left(T_{1}-T_{a}\right) / \mathrm{I}$ a straight line with a negative slope would be obtained. The intercept on the $y$-axis would give the value of $\left[F_{R} \tau \alpha\left(A_{p} / A_{c}\right)\right]$, while the slope of the line would give the value of $\left[F_{R} U_{l}\left(A_{p} / A_{c}\right)\right]$. In Eq. (1), the value of $\eta_{i}$ is based on the collector gross area. It could be based on the absorber plate area also. In that case, the term $\left(A_{p} / A_{c}\right)$ would drop out of Eq. (3). The intercept on the yaxis would then be $\left(F_{R} \tau \alpha\right)$ and the slope of the line would be $\left(F_{R} U_{l}\right)$. Hence,

$$
\eta_{i}=a 0-a 1 \frac{\left(T_{1}-T_{a}\right)}{I}
$$

Equation (6) is widely known as H-W-B equation [9]. Here, the value of $I, T_{1}$ and $T_{a}$ are constant and only values of H-W-B constants ( $a 0$ and $a 1)$ are going to change due to scaling.

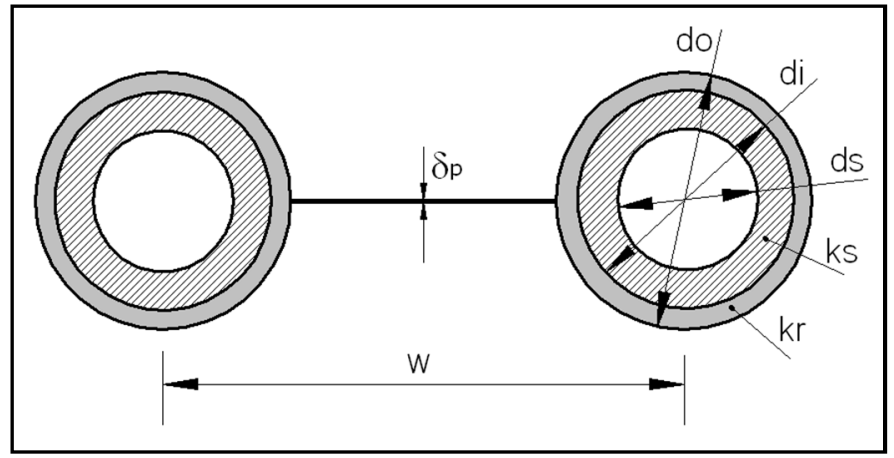

Fig. 2: Risers with scale formation.

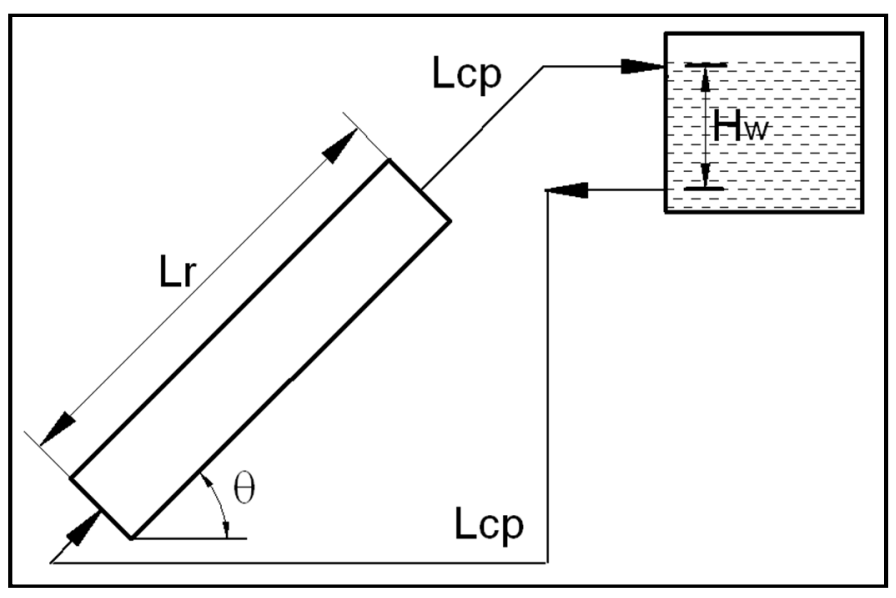

Fig. 3: Thermosiphon head in FPC.

\section{PRESSURE DROP/PRESSURE GAIN IN THE SYSTEM}

The hydrodynamic effects of scaling are restriction in flow area inside the collector and associated increased flow resistance. The pressure gain and drop relationship of the collector are determined as functions of mass flow rate and then solved to find the mass flow rate. The 
pressure drop in the system comprises of frictional drop in risers and headers, connecting pipes, pipe fittings and storage tank. The larger frictional pressure drop occurs in the risers. The pressure difference required for a thermosiphon flow (pressure gain) is due to the density difference between the collector outlet and inlet water [10].

The pressure gain ' $\Delta P_{\text {gain }}$ ' responsible for the flow can be considered in two parts (Fig. 3 ), one representing the pressure gain across the collector ' $\Delta P_{\mathrm{c}}$ ' and the other between the top and bottom of the tank ' $\Delta P_{\text {tank }}$ ' such that

$$
\Delta P_{\text {gain }}=\Delta P_{c}+\Delta P_{\text {tank }}
$$

Let $\mathrm{T}(\mathrm{x})$ is the temperature at distance $\mathrm{x}$ from the inlet of the collector, the pressure due to buoyancy forces ( $\Delta P \mathrm{c}$ and $\Delta P$ tank) can be evaluated by the following equations [11]:

$$
\left.\begin{array}{l}
\Delta P_{c}=g \beta \rho_{2} \sin \theta \int_{0}^{L}(T(x)-T) d x \\
\Delta P_{\text {tank }}=g H_{w}\left(T_{2}-T_{1}\right)
\end{array}\right\}
$$

Then

$$
\Delta P_{\text {gain }}=g \beta \rho_{2} \sin \theta \int_{0}^{L_{r}}(T(x)-T) d x+g H_{w}\left(T_{2}-T_{1}\right)
$$

Equation (9) can be rewritten as [12]

$$
\Delta P_{\text {gain }}=g B \Delta T\left[0.5 H_{r}+H_{w}\right]
$$

The useful heat gain from the riser is

$$
q_{u}=\dot{m} C_{p} \Delta T
$$

The instantaneous efficiency of the riser is the ratio between output and input power of the riser [13].

$$
\eta_{i}=\frac{q_{u}}{I A_{p} / N}
$$

Incorporating (11) and (12) in (10) to get,

$$
\Delta P_{\text {gain }}=\frac{g B I A_{p}}{N C_{p} \dot{m}}\left[0.5 H_{r}+H_{w}\right]\left[a 0-a 1\left(\frac{\left(T_{1}-T_{a}\right)}{I}\right)\right]
$$

The total frictional pressure drop ' $\Delta P_{\text {drop }}$ ' in the circuit can be separated into the contribution from the collector ' $\Delta P_{\mathrm{c}}$ ' and that from the piping components outside the collector ' $\Delta P_{\mathrm{pc}}$ ' as shown in Fig. 4. 


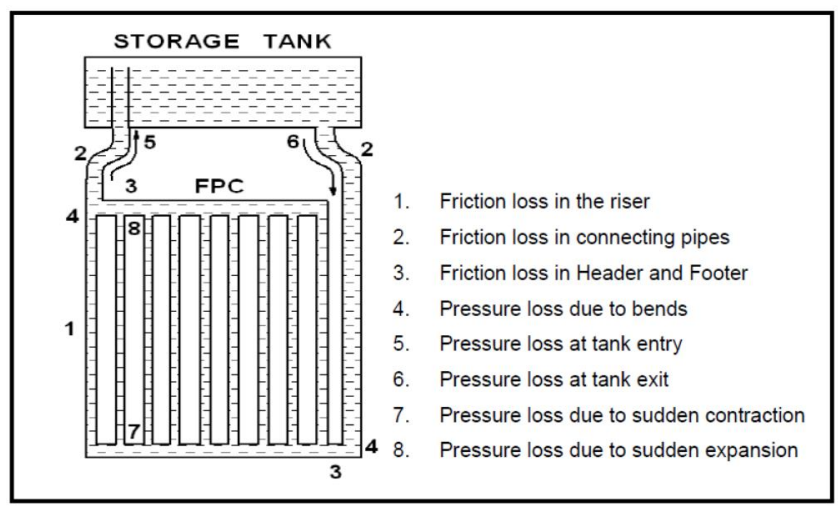

Fig. 4: Various pressure losses in FSWH.

$$
\Delta P_{\text {drop }}=\Delta P_{c}+\Delta P_{p c}
$$

The various losses within the collector $\left(\Delta P_{\mathrm{c}}\right)$ is the sum of friction loss in the risers ' $\Delta P_{r f}$ ', friction loss in the header and footer ' $\Delta P_{h f f}$ ' and losses due sudden contraction and expansion ' $\Delta P_{e c}$ ' in the footer-riser-header assembly.

$$
\Delta P_{c}=\Delta P_{r f}+\Delta P_{h f f}+\Delta P_{e c}
$$

Similarly, different losses encountered in the piping components $\left(\Delta P_{p c}\right)$ are the friction loss in connecting pipes ' $\Delta P_{c p f}$ ', loss due bends fitted to connecting pipe ' $\Delta P_{c p b}$ ' and entry and exit losses at the tank ' $\Delta P_{\text {tank }}$ '.

$$
\Delta P_{p c}=\Delta P_{c p f}+\Delta P_{c p b}+\Delta P_{t a n k}
$$

By considering laminar flow throughout the collector, Eq.(14) is rewritten as

$$
\begin{aligned}
\Delta P_{\text {drop }}= & {\left[\Delta P_{r f}\left(1+\left(\frac{L_{h}}{L_{r}}\right)\left(\frac{d_{i}}{d_{h}}\right)^{4}(1+N)+\left(\frac{L_{c p}}{L_{r}}\right)\left(\frac{d_{i}}{d_{c p}}\right)^{4}(N)\right)\right]+} \\
& {\left[\Delta P_{e c}\left(1+\left(\frac{4}{3}\right)\left(\frac{d_{i}}{d_{c p}}\right)^{4}\left(N^{2}\right)+\left(\frac{d_{i}}{d_{c p}}\right)^{4}\left(N^{2}\right)\right)\right] }
\end{aligned}
$$

Equation (17) gives the pressure drop in case of a clean FPC. But for a scaled FPC the pressure drop is given by

$$
\begin{aligned}
\Delta P_{\text {drop }}= & {\left[\Delta P_{r f}\left(1+\left(\frac{L_{h}}{L_{r}}\right)\left(\frac{d_{S}}{d_{h}}\right)^{4}(1+N)+\left(\frac{L_{c p}}{L_{r}}\right)\left(\frac{d_{S}}{d_{c p}}\right)^{4}(N)\right)\right]+} \\
& {\left[\Delta P_{e c}\left(1+\left(\frac{4}{3}\right)\left(\frac{d_{S}}{d_{c p}}\right)^{4}\left(N^{2}\right)+\left(\frac{d_{S}}{d_{c p}}\right)^{4}\left(N^{2}\right)\right)\right] }
\end{aligned}
$$


For any flow system, if both the thermosiphon/pump pressure gain curve and the pressure drop characteristics of the load are known, the resulting flow rate from the two relationships can be solved [14]. Since both the pressure drop and gain equation are the function of mass flow rate, the actual mass flow rate is that which balances the thermosiphon buoyancy force with the frictional resistance in the circuit as shown in Fig. 5.

By considering the storage tank capacity as $150 \mathrm{~L}$, the average temperature of water in storage tank for any hour is calculated as below:

$$
T_{T}=\frac{\left(V_{T} T_{2}\right)+\left(150-V_{T}\right) T_{1}}{150}
$$

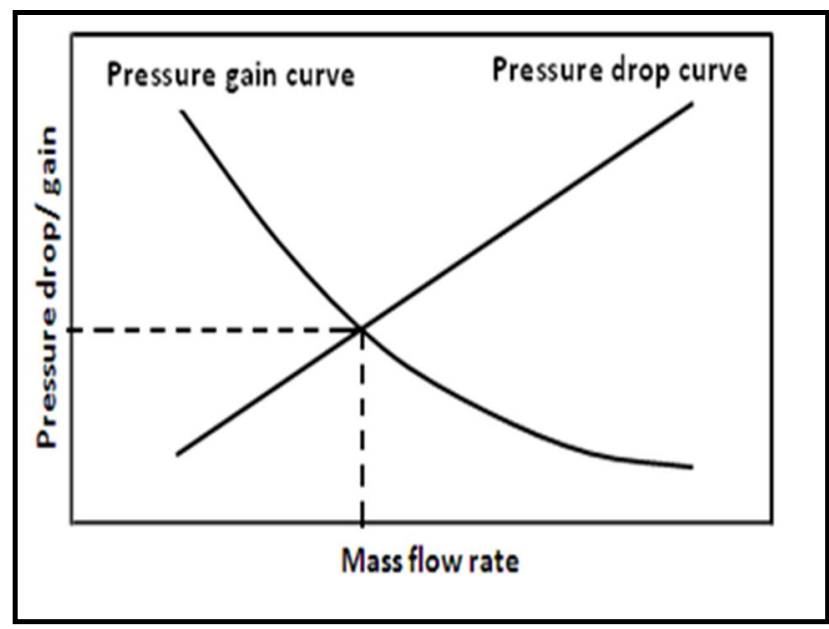

Fig. 5: Pressure drop/gain versus mass flow rate characteristics.

\section{RESULTS AND DISCUSSION}

The detailed analysis of thermosiphon FSWH is done by making use of FLATSCALE. The various energy efficiency parameters like water temperature at collector outlet, water temperature in storage tank, Absorber plate mean temperature, overall heat loss coefficient, mass flow rate etc. are brought out for different scale conditions.

The assumptions made in the analysis are as follows:

- Steady state one dimensional heat conduction

- Thermal conductivity of scale composition is constant

- Absorber plate temperature is uniform throughout the ???

- Absorber plate effectiveness is constant

- Scale formation in risers only; No effect of scaling in header and footer

- Scale growth is uniform and identical in all risers

- Temperature of water in the storage tank is uniform

- No water drawn off during the sunshine hours

- Hourly solar radiation level is constant

- Heat loss from the connecting pipe and storage tank to the surrounding is negligible

- Effect of wind speed is neglected 
In the analytical analysis, a thermosiphon system of size $2 \mathrm{~m} \times 1 \mathrm{~m}$ with storage tank of $150 \mathrm{~L}$ capacity is considered. The detailed specifications and material properties of FSWH are considered. To compare the day long performance with different scale situation, an identical input condition is necessary. Hence, the hourly variation of solar radiation and ambient temperature on a typical clean sky day is incorporated in the analysis and is as shown in Fig. 6. To check the consistency and accuracy of FLATSCALE, it is tested for the convergence of $\mathrm{a} 0$ and a 1 values. The experimental validation of various efficiency indicating parameters is done as a separate study [8].

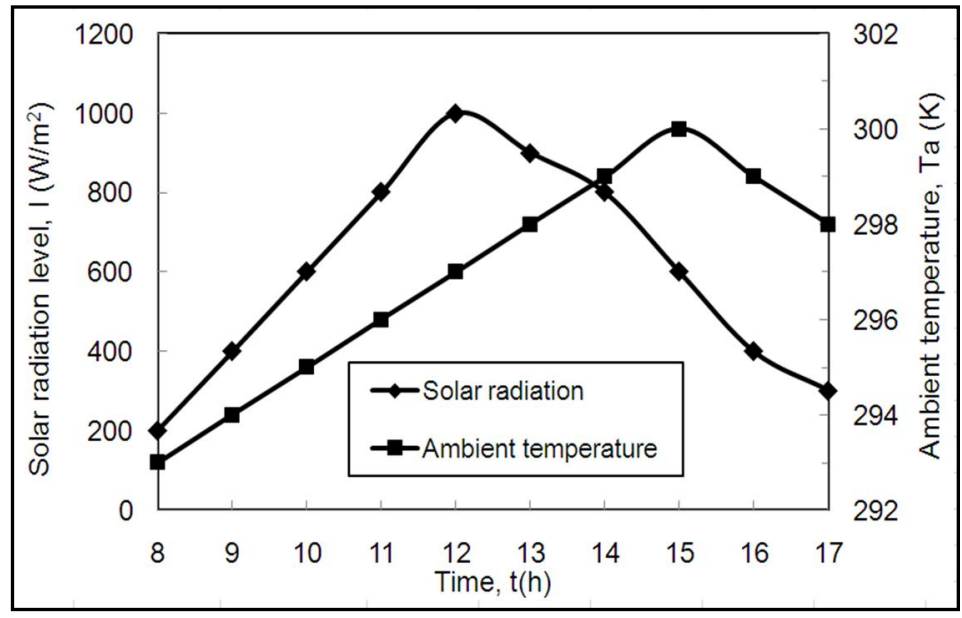

Fig. 6: Variation of solar radiation and ambient temperature with time.

Figure 7 shows the variation of mass flow rate with time for different scale conditions. It shows, the mass flow rate is a strong function of solar radiation. The mass flow rate is maximum during 12 noon as solar radiation level is $1000 \mathrm{~W} / \mathrm{m}^{2}$. The trend of mass flow rate from morning to evening is similar for different scale conditions. The mass flow rate reduces with scale thickness due to rise in pressure drop. The Fig. indicates only $13.8 \%$ drop with 0.7 $\mathrm{mm}$ scaling. This variation widens as the scale thickness increases and in case of $3.7 \mathrm{~mm}$ scaling, the drop in mass flow rate is $89.5 \%$ compared to scale free FPC.

Figure 8 indicates the variation of water outlet temperature with time. In case of a clean FPC, water temperature increases constantly throughout the day. Further, as the scale thickness increases the maximum outlet temperature of water also rises. In case of $3.7 \mathrm{~mm}$ scaling, water attains maximum temperature (close to boiling point) during solar radiation of $1000 \mathrm{~W} / \mathrm{m}^{2}$. Since the mass flow rate is too low, the outlet water temperature trend follows the absorber plate mean temperature curve. It can be observed from the figure that the influence of scaling on water outlet temperature is nominal till $1.7 \mathrm{~mm}$ scale thickness. At the end of the day, the water temperature is fairly same in all cases.

Figure 9 shows the effect of scaling on absorber plate temperature for the entire day. This temperature is directly related to solar radiation level. If the mass flow rate in the system is considerable, the rise in absorber plate temperature is limited as in the case of $0 \mathrm{~mm}, 0.7 \mathrm{~mm}$ and $1.7 \mathrm{~mm}$. In case of $2.7 \mathrm{~mm}$ and $3.7 \mathrm{~mm}$ scale thickness, the rise is credible as the mass flow rate is reduced. 
Figure 10 shows the variation of average temperature of water in the storage tank. The drop in temperature noted is $0.7 \mathrm{~K}$ in $0.7 \mathrm{~mm}$ scale thickness to $15.3 \mathrm{~K}$ in case of $3.7 \mathrm{~mm}$ scaling. The analytical result clearly indicates that even though the efficiency of FPC is reduced drastically with scaling, its effect on performance of FSWH is not severe. This is due to lower mass flow rate with higher water temperature at collector outlet. The plot presents the upward trend in tank temperature throughout the day. But this rise is highly time based. As indicated, in the $8-10 \mathrm{hr}$ and $14-17 \mathrm{hr}$ region the rise is not sharp compared to $10-14 \mathrm{hr}$ region. This is due to higher solar radiation level and better heat carrying capacity of water.

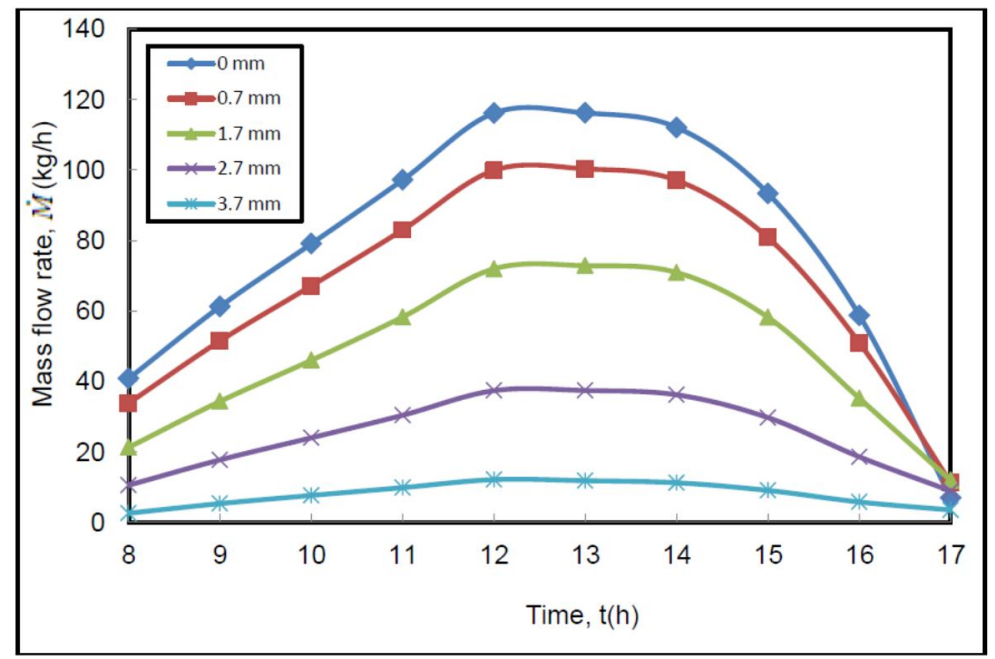

Fig. 7: Variation of mass flow rate with time.

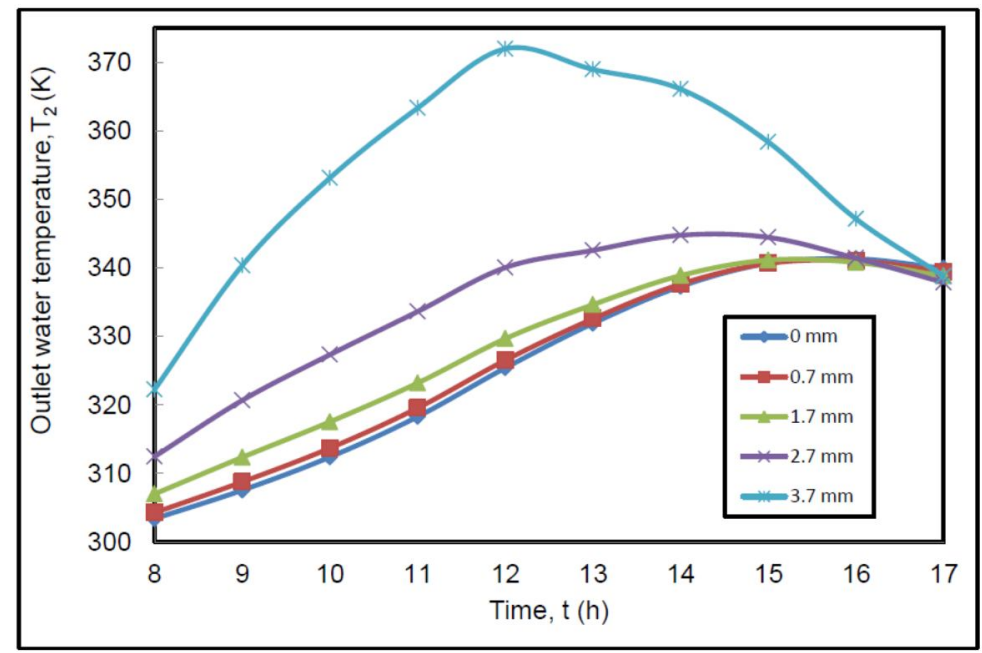

Fig. 8: Variation of water outlet temperature with time. 


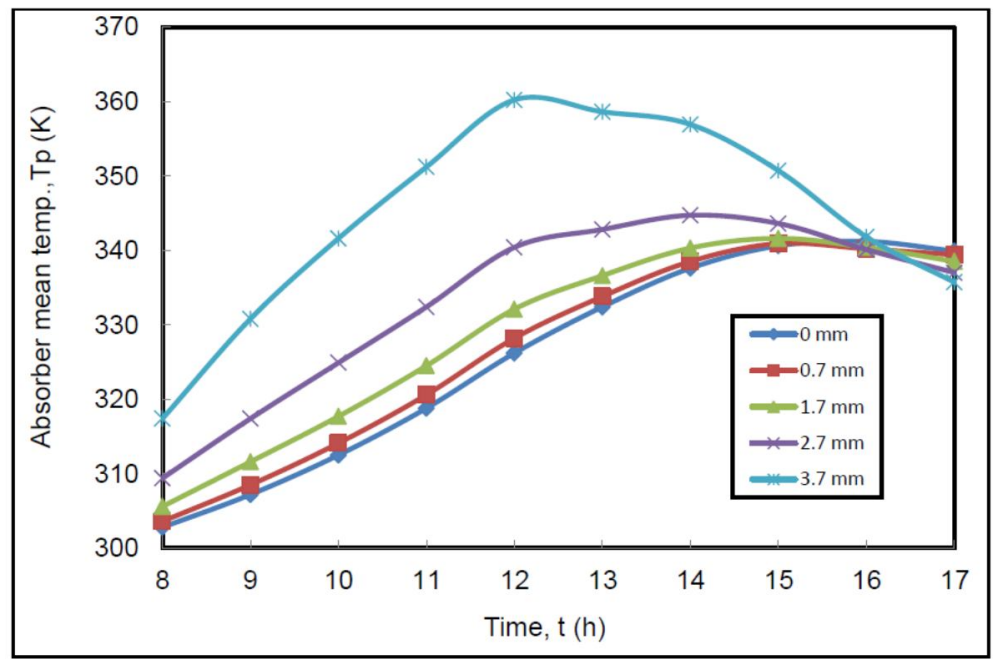

Fig. 9: Variation of Absorber plate mean temperature with time.

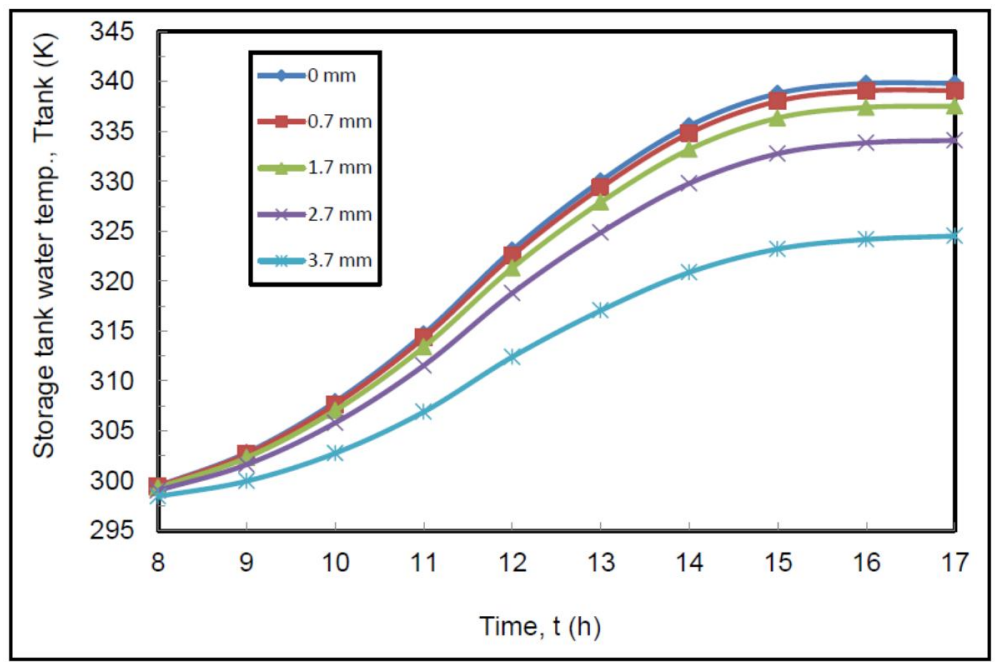

Fig. 10 : Variation of water temperature in tank with time. 


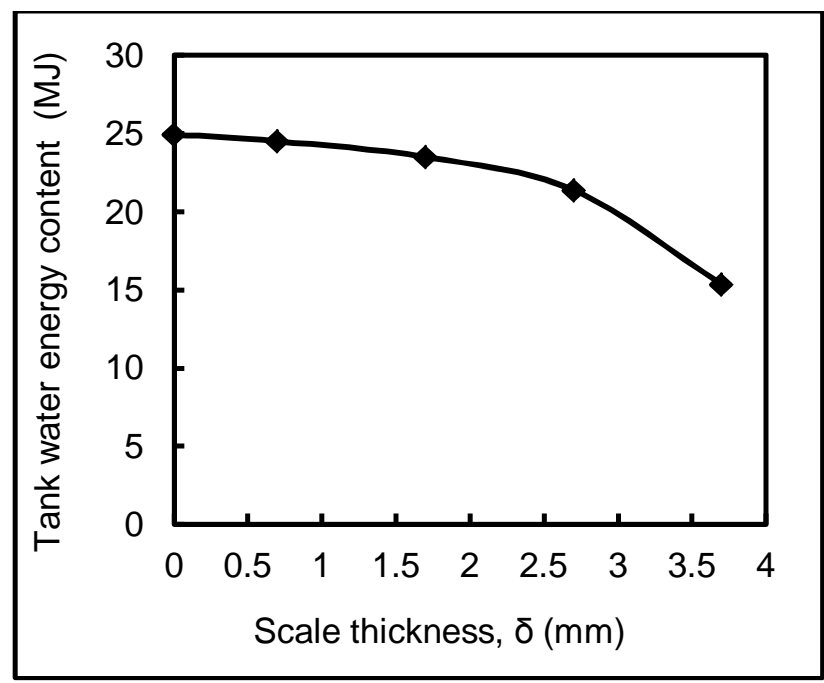

Fig. 11 : Variation of water energy content with scale thickness.

Figure 11 shows the storage tank water energy content during the day end by taking ambient temperature as $300 \mathrm{~K}$. As indicated, the loss of energy gain is $6 \%$ for $1.7 \mathrm{~mm}$ scaling and in case of $3.7 \mathrm{~mm}$ scale thickness, the energy gain drops by $38 \%$. The analytical result revealed the effect of uniform scaling in risers on water temperature in the storage tank as less significant. But, practically the scale growth pattern is not uniform. From the field study it is understood that, the growth is minimum to maximum from footer to header. For the initial growth of 1-2 $\mathrm{mm}$, the scale coating is more or less concentric with the riser and further scale growth leads to complete blockage of some of the risers and partial opening of the rest. Under this situation, the drop in storage tank water temperature is considerable and such result obviously deviates from analytical result. To understand its effect on two different cases are considered. In case of $2.7 \mathrm{~mm}$ scale thickness, 3 risers are blocked and for the thickness of $3.7 \mathrm{~mm}, 6$ risers are blocked. These results are compared with $0 \mathrm{~mm}, 0.7 \mathrm{~mm}$ and $1.7 \mathrm{~mm}$ cases and shown in Fig. 12. It shows that the maximum storage tank water temperature in case of 2.7 $\mathrm{mm}$ scale thickness with three risers blocked is $322 \mathrm{~K}$ compared to $334 \mathrm{~K}$ for $2.7 \mathrm{~mm}$ thickness without riser blockage. If the water flow rate through the FPC is stopped, there is no useful heat gain and the efficiency is zero. In this case, the absorber plate attains temperature called Stagnation temperature. Figure 12 shows the variation of stagnation temperature with time. The maximum temperature observed is $408 \mathrm{~K}$.

Figure 13 presents the deviation of overall loss coefficient with solar radiation level. Since both bottom and side loss coefficients are constant and top loss coefficient is a strong function of absorber plate temperature, the trend in absorber plate variation is repeated here. 


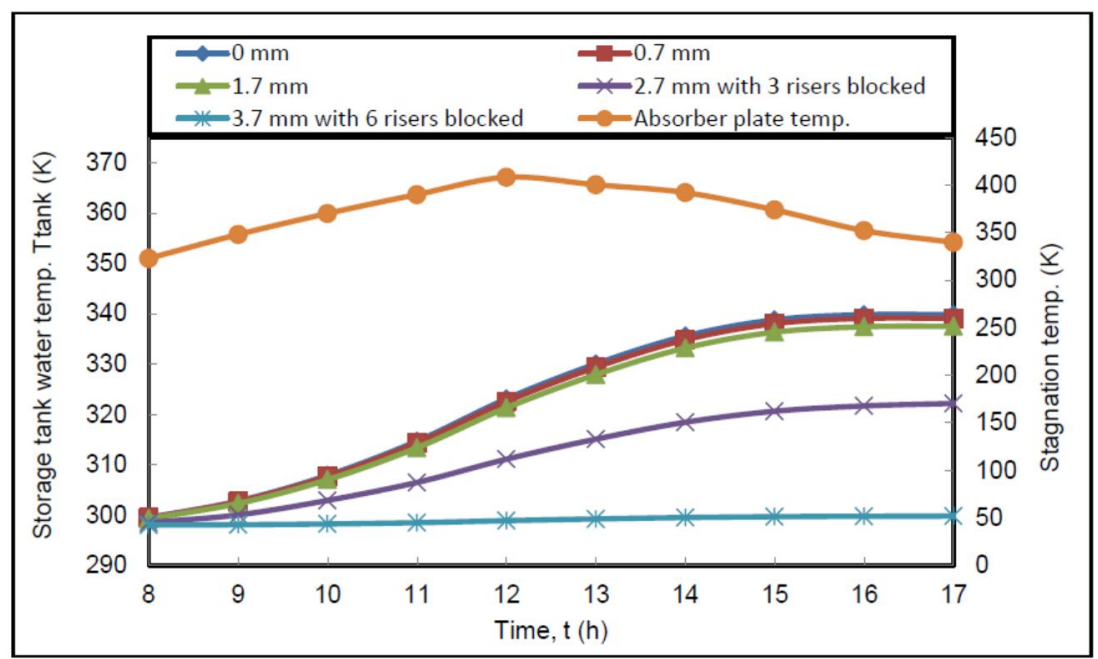

Fig. 12: Variation of temperature with time.

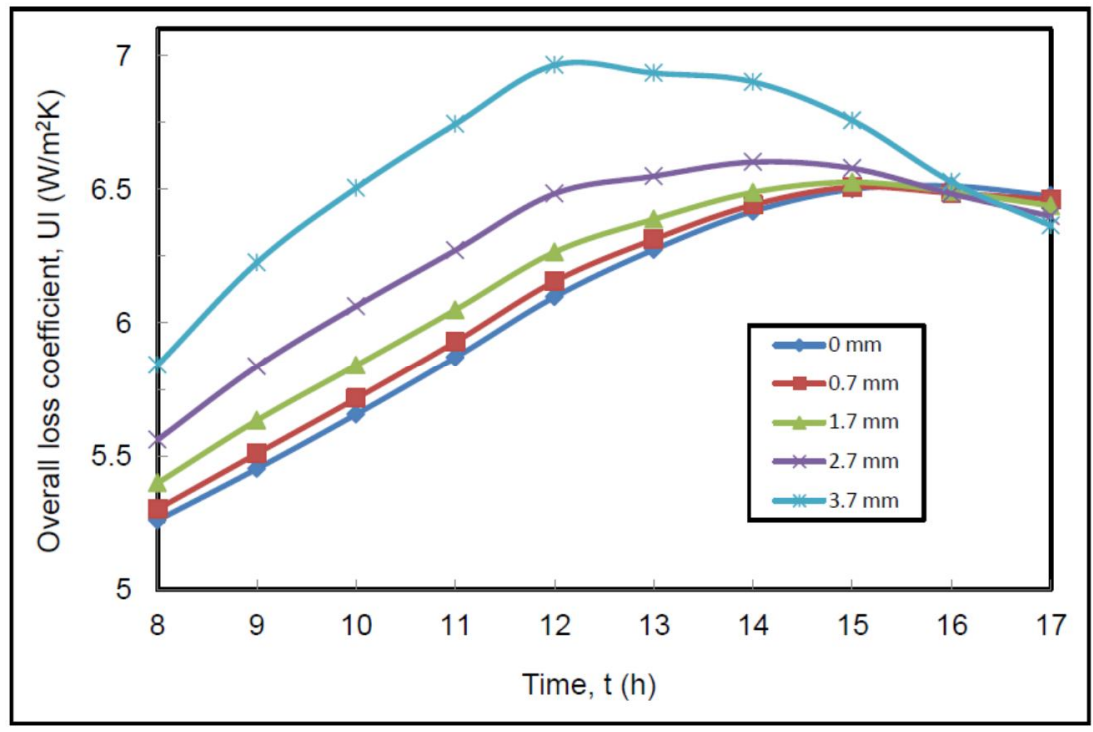

Fig. 13: Variation of overall loss coefficient with time.

Figure 14 shows the variation in a0 value for different scaling with time. This is an important parameter in calculating the instantaneous efficiency of FPC. Since ' $\tau \alpha$ ' is taken as constant, this variation is directly coupled to collector heat removal factor. Generally, for the given design and working condition, a0 is relatively constant. But under no scale condition, the sharp decline in a0 value is noted during the end of day. This is due to the absorption of only part of available radiation as water is already carried sufficient heat. Plot shows considerable drop in a0 value with $2.7 \mathrm{~mm}$ and $3.7 \mathrm{~mm}$ thickness of scale.

Figure 15 indicates the deviation of a1 for different scale condition with time. The trend observed here is similar. Since it is a product of $F_{R}$ and $U_{l}$, under scaled conditions the value of $F_{R}$ reduces and $U_{1}$ increases. But the drop in $F_{R}$ value is significant compare to rise in value of $\mathrm{U}_{1}$, hence a1 decreases with different scaling conditions. 


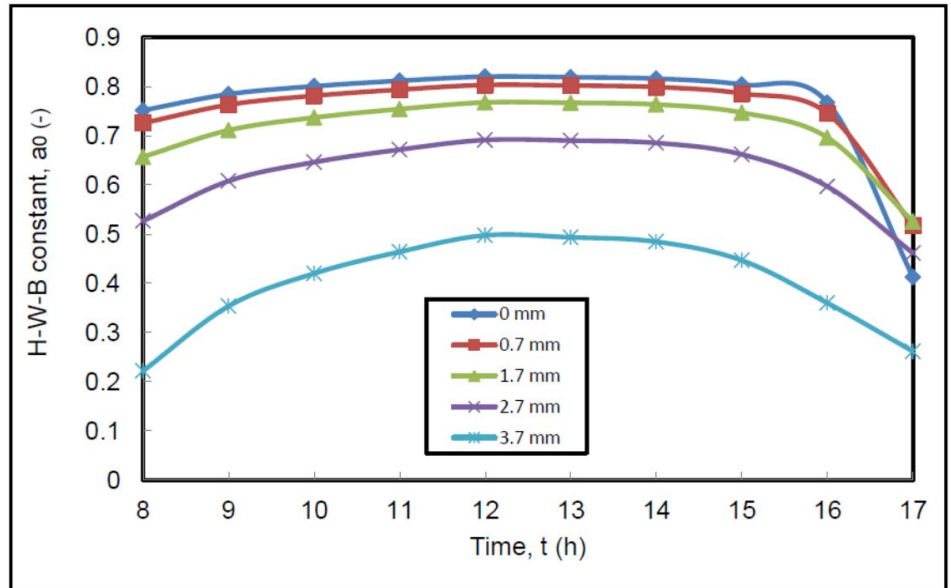

Fig. 14: Variation of a0 with time.

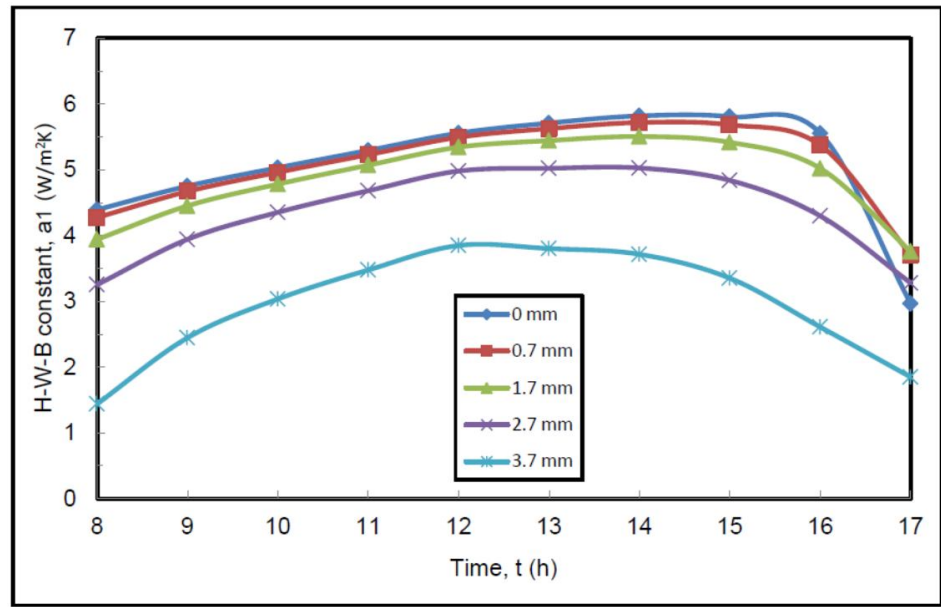

Fig. 15: Variation of a1 with time.

\section{CONCLUSION}

The application of software to thermosiphon system has given the instantaneous efficiency as $72 \%$ under clean condition for $1000 \mathrm{~W} / \mathrm{m}^{2}$ solar radiation and it dropped to 46 $\%$ in case of $3.7 \mathrm{~mm}$ scale thickness. The mass flow rate was reduced by $90 \%$ for $3.7 \mathrm{~mm}$ scale thickness and the highest temperature observed was $371 \mathrm{~K}$. During no flow condition, absorber plate temperature reached was $408 \mathrm{~K}$. Under severe scaling, the energy gain drops by $38 \%$. . This was due to assumed condition of uniform and concentric scale growth in the risers. But in field, under such condition upper portion of most of the risers will be blocked and leads to negligible rise in tank water temperature. 


\section{REFERENCES}

[1] D.J. Close, The performance of solar water heaters with natural circulation, Solar Energy, No.6, 1962, pp. 33-40

[2] C. L. Gupta and H P Garg, System design in solar water heaters with natural circulation. Solar Energy, No.12, 1968, pp. 163-182

[3] N. E. Wijeysundera, M. N. A. Hawlader and K. Y. Foong, Estimation of Collector Performance Parameters From Daily System Tests, Solar energy(ASME), Vol.118, February 1996, pp 30-36

[4] Y. Raja Sekhar, K. V. Sharma and M. Basaveswara Rao, Evaluation of Heat loss coefficients in solar flat plate collectors, ARPN Journal of Engineering and Applied Sciences, Vol. 4, July 2009, pp. 15-19

[5] Patricia Sanft, Lorraine F. Francis and Jane H. Davidson, Calcium Carbonate Formation on CrossLinked Polyethylene (PEX) and Polypropylene Random Copolymer (PP-r), Solar energy (ASME), Vol.128, 2006, pp. 251-254

[6] Zhen $\mathrm{Wu}$, Lorraine F. Francis and Jane H. Davidson, Scale formation on polypropylene and copper tubes in mildly supersaturated tap water, Solar Energy, 2009, pp. 636-645

[7] Derek Baker and Gary Vliet, Designing Solar Hot Water Systems for Scaling Environments, Solar Energy (ASME), Vol. 123, Feb. 2001, pp.43-47

[8] U. C. Arunachala, M. Siddhartha Bhatt and L. K. Sreepathi, Scaling Effect of Direct Solar Hot Water Systems on Energy Efficiency, Solar Energy (ASME), Vol. 132, November 2010

[9] Duffie J. A. and Beckman W.A., Solar Engineering of Thermal Processes, $2^{\text {nd }}$ ed., Wiley Interscience, New York, 1991

[10] G. L. Morrison and B. J. Ranatunga, Thermosyphon circulation in solar collectors, Solar energy, Vol. 24, pp $191-198,1980$

[11] A. Zerrouki , A. Boumedien and K. Bouhadef, The natural circulation solar water heater model with linear temperature distribution, Renewable Energy, 2002, pp. 549-559

[12] U. C. Arunachala, Siddhartha Bhatt M. and Sreepathi L. K., Performance analysis of solar flat plate collectors in scaling environment, Journal of Central Power Research Institute, Vol. 5, No.1, 2009, pp.109-119

[13] U. C. Arunachala, M. Siddhartha Bhatt and L. K. Sreepathi, "Prediction, Evaluation and Prevention of scaling in flat plate solar water heaters", Emerging Journal on Engineering Science and Technology, Vol. 4, Sept. 2009, pp. 37-52

[14] Boehm Robert F., Design analysis of thermal systems, John Willey \& Sons, New York, 1987

\section{NOMENCLATURE}

a0 Intercept of the $\mathrm{H}-\mathrm{W}-\mathrm{B}$ equation

a1 Slope of $\mathrm{H}-\mathrm{W}-\mathrm{B}$ equation

A Area

B Constant relating density to temperature

Cp Specific heat of water

d Diameter

$\mathrm{F}^{\prime} \quad$ Collector efficiency factor

$\mathrm{F}_{\mathrm{R}} \quad$ Collector heat removal factor

-
$\mathrm{W} / \mathrm{m}^{2} \mathrm{~K}$
$\mathrm{~m}^{2}$
$\mathrm{~kg} / \mathrm{m}^{3} \mathrm{~K}$
$\mathrm{~kJ} / \mathrm{kgK}$
$\mathrm{m}$
-
-




\begin{tabular}{|c|c|c|}
\hline $\mathrm{g}$ & Acceleration due to gravity & $\mathrm{m} / \mathrm{s}^{2}$ \\
\hline $\mathrm{h}$ & Convective coefficient of water in riser & $\mathrm{W} / \mathrm{m}^{2} \mathrm{~K}$ \\
\hline $\mathrm{H}$ & Height & $\mathrm{m}$ \\
\hline I & Total flux incident on the top glass cover & $\mathrm{W} / \mathrm{m}^{2}$ \\
\hline $\mathrm{k}$ & Thermal conductivity of material & $\mathrm{W} / \mathrm{mK}$ \\
\hline $\mathrm{L}$ & Length & $\mathrm{m}$ \\
\hline $\mathrm{N}$ & Number of risers in FPC & - \\
\hline$\Delta \mathrm{P}$ & Pressure change & $\mathrm{N} / \mathrm{m}^{2}$ \\
\hline q & Rate of heat flow in riser & $\mathrm{W}$ \\
\hline Q & Rate of heat flow in FPC & $\mathrm{W}$ \\
\hline $\mathrm{T}$ & Temperature & $\mathrm{K}$ \\
\hline $\mathrm{U}$ & Collector heat transfer coefficient & $\mathrm{W} / \mathrm{m}^{2} \mathrm{~K}$ \\
\hline V & Vol. of water circulated in $1 \mathrm{hr}$. & litres \\
\hline $\mathrm{W}$ & Pitch of risers & $\mathrm{m}$ \\
\hline$\dot{m}$ & Mass flow rate of water in riser & $\mathrm{kg} / \mathrm{s}$ \\
\hline$\dot{M}$ & Mass flow rate in FSWH & $\mathrm{kg} / \mathrm{s}$ \\
\hline$\alpha$ & absorber plate absorptivity & - \\
\hline$\beta$ & Coefficient of cubical expansion & $\mathrm{K}^{-1}$ \\
\hline$\eta$ & efficiency & - \\
\hline$\theta$ & collector / riser orientation & degree \\
\hline$\rho$ & mass density of water & $\mathrm{kg} / \mathrm{m}^{3}$ \\
\hline$\tau$ & glass cover transmissivity & - \\
\hline$\varphi$ & absorber plate effectiveness & - \\
\hline $\mathrm{a}$ & ambient air & \\
\hline $\mathrm{c}$ & collector & \\
\hline $\mathrm{cp}$ & connecting pipe & \\
\hline h & header & \\
\hline $\mathrm{i}$ & instantaneous, inner & \\
\hline 1 & loss & \\
\hline o & outer & \\
\hline $\mathrm{p}$ & absorber plate & \\
\hline $\mathrm{r}$ & riser & \\
\hline S & scale & \\
\hline $\mathrm{T}$ & $\operatorname{tank}$ & \\
\hline
\end{tabular}




u useful

w water

$1 \quad$ water inlet

2 water outlet 